\title{
Assessment of Facilities, Knowledge and Counseling on Handwashing of Elementary School Students in the District of North Bogor
}

\author{
Totih Ratna Sondari, Basuki Rachmat , Amir Suudi, Bhaskarani Widjiastuti and Ida \\ National Institute of Research and Development, Ministry of Health of Republic of Indonesia, Jakarta, Indonesia; \\ basukir2009@gmail.com
}

\begin{abstract}
This cross-sectional study was conducted in the district of North Bogor to find out the relationship of facilities, knowledge and counseling to the level of behavior of the handwashing of elementary school students. This research is a quantitative study, accompanied by observations of the availability of handwashing facilities in schools. Data characteristics, facilities, counseling, behavior and knowledge of students were collected using a questionnaire. Three hundred fifty-five students (51.8\% were male) registered in this study. The average age of students is 10 years $(73.0 \%)$. The availability of facilities such as hand washing facilities (100\%), toilets $(100 \%)$, clean water $(97.7 \%)$, running water $(82.0 \%)$ and soap $(91.3 \%)$ in schools is quite complete. The behavior of students using soap when washing their hands (76.1\%), after defecating small (88.7\%), and after handling animals (82.0\%). Students' knowledge about correct hand washing (73.8\%), the exact duration of handwashing (22.8\%). In the logistic regression analysis, gender, age and counseling were not significantly related to student behavior. However, facilities $(\mathrm{P}=0.011)$ and knowledge $(\mathrm{P}=0.037)$ are related to students' handwashing behavior. Observation found that the availability of washbasket facilities in five schools was in good condition and functioning normally as well as the standard operational procedures for handwashing in schools, but placed in a location that is not visible to students. In short, students' handwashing behavior is still lacking, especially among students who are in schools with inadequate facilities and have less knowledge about handwashing.
\end{abstract}

Keywords: Attitude, Counseling, Facilities, Handwashing with Soap, Knowledge, Students

\section{Introduction}

Diarrheal disease and respiratory infections are major contributors to global child mortality, estimated at around 1.7 million child deaths annually ${ }^{1}$. Transmission mainly occurs in schools, where students are in close contact with each other, such as classrooms in urban middle-to-lower-income environments tend to be overcrowded because of the limited amount of space $\left(<2 \mathrm{~m}^{2} / \text { person }\right)^{2}$. Infectious diseases are the main cause which results in the loss of student attendance at school, where absenteeism is associated with low academic achievement ${ }^{3,4}$. It is estimated that hundreds of millions of school days are lost each year globally due to diarrheal disease ${ }^{5}$. Handwashing education and promotion are proven strategies to reduce diarrhea and respiratory disease globally ${ }^{6}$.

Handwashing with Soap (HWWS) is one of the prevention efforts through sanitation measures by cleaning hands and fingers using water and soap ${ }^{7}$. Recommendations for a good duration of wash with soap ranges from 20-40 seconds ${ }^{7,8}$.
Washing hands with soap reduce the incidence of diarrheal disease in children and adults ${ }^{9,10}$; protects against respiratory infections including pneumonia ${ }^{10,11}, \mathrm{H} 1 \mathrm{~N} 1$ influenza $^{12}$, and worm infections ${ }^{13}$. A research in Cairo, Egypt, conducted randomized control trials in 60 primary schools, by intervening handwashing twice a day and given health messages through entertainment activities to children in schools. The results of this study show that, in the intervention group, the overall absence caused by ILI, diarrhea, conjunctivitis, and influenza laboratory-confirmed reduced by $40 \%, 30 \%, 67 \%$ and $50 \%$ ( $<<0,0001$ for each disease). Improved hand hygiene can also improve child development and school attendance ${ }^{12,14}$. The promotion of hand hygiene promotion has become one of the most cost-effective interventions for the prevention of infectious diseases ${ }^{15}$.

Hand hygiene programs implemented in schools in various countries have yielded mixed results. Handwashing interventions have succeeded in reducing absenteeism associated with diseases in Egypt and China but not in rural

${ }^{*}$ Author for correspondence 
Kenya and Israel ${ }^{12,16-18}$. In the study, adherence to hand hygiene directly affects health effects, but on the other hand, it depends on the availability of water and soap. UNICEF estimates that more than 620 million children worldwide do not have essential sanitation services (improved one-sex facilities) in their schools. And more than 900 million children worldwide do not have essential cleaning services (handwashing facilities with water and soap) in their schools ${ }^{19}$.

The awareness of the Indonesian people to wash their hands with soap (HWWS) has improved, recorded the results of Basic Health Research in 2007, 2013 and 2018, showing that the proportion of the population aged $\geq 10$ years who behaved properly hand washing in Indonesia increased from $23.2 \%$ in 2007 , to $47.0 \%$ in 2013 and to $49.8 \%$ in $2018^{20-22}$. In 2013 people in the city of Bogor who behaved adequately wash their hands still below the national rate of $42.3 \%$. The prevalence of the diarrheal disease in Bogor city based on being diagnosed with symptoms is $7.9 \%$, while the diarrheal disease with diagnosis results is $4.2 \%{ }^{20}$.

One effort to be able to improve the culture of washing hands with soap is to improve student behavior through an environmental push and educational program, including the completeness of handwashing facilities, counseling and behavioral formation data about the behavior of washing hands of elementary school students in the North Bogor District area can be valuable information for managers of local health promotion programs for health business planning in schools. This study aims to determine the relationship of facilities, knowledge, and counseling with the level of handwashing behavior of elementary school students.

\section{Methods}

The study design was cross-sectional. Quantitative data collection accompanied by observations at school. Quantitative data obtained through interviews using a structured questionnaire consisting of questions about the availability of facilities for washing hands, knowledge, and attitudes of students at school. Observation aims to determine the implementation of HWWS program policies, the availability of facilities and handwashing materials in the school environment. The location of this study is in five schools in the North Bogor District, Bogor City, West Java Province, Indonesia. The population in this study was public elementary school students in the District of North Bogor. The sample in this study was grade 5 students drawn from five public elementary schools that had received information related to the HWWS program.

The sample is calculated with the Lemeshow formula to test the hypothesis test ${ }^{23}$. The reliability coefficient (z score) 1.96 at the $95 \%$ confidence level, $5 \%$ error margin and the proportion of $42.3 \%{ }^{20}$. The expected value of the population proportion of $51.3 \%$ were entered into the formula to determine a minimum sample size of 320 . Adjusting the nonresponse rate to $10 \%$ gave a total sample size of 355 . Sample selection by simple random sampling from 5 selected primary elementary schools, each school will be taken as many as 71 grades V. the implementation of research for eight months, from March to October 2018.

Quantitative data analysis uses univariate, bivariate and multivariate analysis. The univariate analysis aims to explain the characteristics of each research variable. Analysis of the means, behavior and knowledge variables are measured using Likert scale data ${ }^{24}$. Assessment of the means variable uses five questions about the facility and handwashing ingredients. Value 1 (if any) and 0 (if not). Assessment of behavior variables using seven questions about the behavior of students' handwashing practices. Value 2 (if yes), 1 (if sometimes) and 0 (if not). The assessment of knowledge variables uses sixteen questions about handwashing knowledge. Value 1 (if true) and 0 (if not). The total score was analyzed using the KolmogorovSmirnov test to test normality and if the data were standard, then the mean value was used. If the data were not standard, then the median value was used to determine the cut-off point for the variable knowledge variable good or not good.

Chi-Square Test for the relationship between facility facilities, knowledge and counseling on students' handwashing behavior. Chi-Square Test for the relationship between facility facilities, knowledge and counseling on students' handwashing behavior. A value of $\mathrm{P}<0.05$ describes a statistically significant relationship between variables. The Logistic Regression Test explains the most related factor, with handwashing behavior as the dependent variable. Independent variables (age, gender, facility facilities, knowledge and counseling) were included in the model if the bivariate selection P-value $<0.25$. The odds ratio (OR), 95\% Confidence Interval (CI), and P-value $<0.05$ explain a statistically significant relationship. ${ }^{25}$

\section{Results}

Three hundred 55 students (51.8\% were male) registered in this study (Table 1). Of these 184 (51.8\%) were men, aged $\leq 10$ years (97.2\%), had received counseling in the HWWS program in schools $294(82.8 \%)$, had good knowledge $262(73.8 \%)$, the behavior of applying HWWS is good 205 (57.7\%) and the statement of the existence of disablement facilities in schools is $263(74.1 \%)$. In general, information about HWWS was obtained from counseling by health workers $(83.7 \%)$, through television information media (36.1\%), radio (6.5\%) internet (28.2\%), and magazines/newspapers/brochures. (14.9\%).

In Table 2, related to the perception of the availability of handwashing facilities, all students argued that in schools, there were hand washing facilities $(100 \%)$ and toilets $(100 \%)$ 
with permanent buildings. As for the availability of clean water (97.7\%), running water $(82.0 \%)$ and soap (91.3\%), not all students think that handwashing materials are always available when needed.

The results in Table 3, showed that the proportion of handwashing behavior with soap after defecation was $88.7 \%$, $85.3 \%$ for male students and $92.4 \%$ for female students). While the proportion of handwashing behavior using soap after handling animals $(82.0 \%)$, in male students $(81.5 \%)$ and female students $(82.5 \%)$. The lowest proportion there is in the behavior of students using soap when washing (76.1\%), male students (73.4\%) and female students (78.9\%). From these results, the average proportion of female student behavior is slightly better than male students.

Student knowledge about the possible time spent washing hands with soap is still low (22.8\%). Students' knowledge is good when asked about disease transmission due to dirty hand washing $(80.8 \%)$, benefits of washing hands $(88.7 \%)$, the transmission of disease due to not washing hands $(87.6 \%)$, hand washing material (86.2\%), hand washing stages $(85.6 \%)$ and government programs related to sanitation (87.6\%) while the first assessment of knowledge is in the other nine questions (Table 4).

Table 1. Characteristics of elementary school students in Bogor Tengah District $(\mathrm{n}=355)$

\begin{tabular}{|l|c|c|}
\hline Variable & Total & (\%) \\
\hline Gander (Male) & 184 & 51,8 \\
\hline Age ( $\leq 10$ years) & 269 & 75.8 \\
\hline Hand washing counseling & 294 & 82.8 \\
\hline Handwashing knowledge & 262 & 73.8 \\
\hline Handwashing behavior & 205 & 57.7 \\
\hline Facilities for washing hands & 263 & 74.1 \\
\hline
\end{tabular}

Table 2. Availability of facilities for washing hands of students at school $(\mathrm{n}=355)$

\begin{tabular}{|l|c|c|}
\hline Question & Total & (\%) \\
\hline $\begin{array}{l}\text { Are there clean water facilities } \\
\text { available in school? }\end{array}$ & 347 & 97.7 \\
\hline $\begin{array}{l}\text { Are our washing facilities available } \\
\text { at school? }\end{array}$ & 355 & 100 \\
\hline $\begin{array}{l}\text { Is there always running water } \\
\text { available in the hand washing area? }\end{array}$ & 291 & 82.0 \\
\hline $\begin{array}{l}\text { Is soap available in the hand } \\
\text { washing area? }\end{array}$ & 324 & 91.3 \\
\hline $\begin{array}{l}\text { Are there Toilets available at your } \\
\text { school? }\end{array}$ & 355 & 100 \\
\hline
\end{tabular}

Table 3. Student behavior in washing hands with soap $(\mathrm{n}=355)$

\begin{tabular}{|l|c|c|c|c|c|}
\hline \multirow{2}{*}{ Question } & \multicolumn{2}{|c|}{$\begin{array}{c}\text { Male } \\
(\mathbf{n}=\mathbf{1 8 4})\end{array}$} & \multicolumn{2}{c|}{$\begin{array}{c}\text { Female } \\
(\mathbf{n}=\mathbf{1 7 1})\end{array}$} & \multirow{2}{*}{$\begin{array}{c}\text { Total } \\
(\%)\end{array}$} \\
\cline { 2 - 5 } & $\mathbf{n}$ & $\mathbf{( \% )}$ & $\mathbf{n}$ & $(\%)$ & \\
\hline $\begin{array}{l}\text { Do wash hands with soap } \\
\text { after urinating/defecating? }\end{array}$ & 157 & 85.3 & 158 & 92.4 & $\begin{array}{c}315 \\
(88.7)\end{array}$ \\
\hline $\begin{array}{l}\text { Do wash hands with soap } \\
\text { after handling animals? }\end{array}$ & 150 & 81.5 & 141 & 82.5 & $\begin{array}{c}291 \\
(82.0)\end{array}$ \\
\hline $\begin{array}{l}\text { Do wash hands with soap } \\
\text { before eating? }\end{array}$ & 161 & 87.5 & 155 & 90.6 & $\begin{array}{c}316 \\
(89.0)\end{array}$ \\
\hline $\begin{array}{l}\text { How often do wash hands } \\
\text { with soap? }\end{array}$ & 135 & 73.4 & 135 & 78.9 & $\begin{array}{c}270 \\
(76.1)\end{array}$ \\
\hline $\begin{array}{l}\text { Do wash hands with soap if it } \\
\text { looks dirty or smells bad? }\end{array}$ & 176 & 95.7 & 157 & 91.8 & $\begin{array}{c}333 \\
(93.8)\end{array}$ \\
\hline $\begin{array}{l}\text { Do wash hands with } \\
\text { clean water in the school } \\
\text { environment? }\end{array}$ & 178 & 96.7 & 169 & 98.8 & $\begin{array}{c}347 \\
(97.7)\end{array}$ \\
\hline $\begin{array}{l}\text { Do always wash hands with } \\
\text { running water in the washing } \\
\text { place? }\end{array}$ & 184 & 100.0 & 171 & 100.0 & $\begin{array}{c}355 \\
(100)\end{array}$ \\
\hline
\end{tabular}

Chi-Square test results obtained a large number of students who behaved significantly less male sex $(\mathrm{OR}=1.5,95 \% \mathrm{CI}$ $0.96-2.24, \mathrm{P}=0.048)$, were in poor facilities $(\mathrm{OR}=1.94,95 \%$ CI $1.2-3.14, \mathrm{P}=0.005)$ and had less knowledge $(\mathrm{OR}=1.6$, $95 \%$ CI $0.98-2.56, \mathrm{P}=0.039)$ compared to those who had good behavior (Table 5). There is no significant relationship in terms of age and counseling between students with good behavior and students with less behavior.

In logistic regression analysis, facility facilities $(\mathrm{OR}=1.9$, 95\% CI 1.15-3.03, $\mathrm{P}=0.011$ ), and knowledge ( $\mathrm{OR}=1.7,95 \%$ CI 1.05-2.75, P = 0.037) have a significant relationship with students' hand washing behavior (Table 6).

The results of observations found that some schools have implemented a handwashing program with soap properly, such as the existence of the Standard Operating Procedure (SOP) on how to wash hands recommended by WHO. SOPs installed in the school environment, but their location is less strategic, so they do not educate students in the field. School support in terms of facilities and infrastructure is sufficient, as seen in all schools that have tried to provide sink in the bathroom, for the availability of a sink in the UKS room and a small proportion of schools only does the canteen. Observation of Health Facilities shows that all schools have provided a source of clean water, toilets, a place for washing hands, running water in a place to wash hands, soap in a place to wash hands and drainage water. However, the availability of soap, running water, and clean water in the hand washing area needs more attention, because there are still schools that do not provide soap. 
Table 4. Knowledge of Handwashing with Soap (HWWS) $(n=355)$

\begin{tabular}{|c|c|c|c|c|c|}
\hline \multirow{2}{*}{ Question } & \multicolumn{2}{|c|}{ Male } & \multicolumn{2}{|c|}{ Female } & \multirow{2}{*}{$\begin{array}{c}\text { Total } \\
(\%)\end{array}$} \\
\hline & $\mathbf{n}$ & $(\%)$ & $\mathbf{n}$ & $(\%)$ & \\
\hline Do think need to wash hands with soap before eating? & 183 & 99.5 & 167 & 97.7 & $350(98.6)$ \\
\hline Does human waste contain germs? & 178 & 96.7 & 168 & 98.2 & $346(97.5)$ \\
\hline Can germs be obtained when we touch tables, doors, books, and animals? & 173 & 94.0 & 165 & 96.5 & $338(95.2)$ \\
\hline Does washing hands improperly, can cause disease? & 170 & 92.4 & 161 & 94.2 & $331(93.2)$ \\
\hline Is washing hands enough with water alone? & 179 & 97.3 & 163 & 95.3 & $342(96.6)$ \\
\hline After coughing or sneezing, is it necessary to wash hands with soap? & 175 & 95.1 & 163 & 95.3 & $338(95.2)$ \\
\hline Does washing unclean hands can transmit the disease? & 146 & 79.3 & 141 & 82.5 & $287(80.8)$ \\
\hline Specify the steps for proper handwashing? & 177 & 96.2 & 165 & 96.5 & $342(96.3)$ \\
\hline When is the right time to wash hands? & 181 & 98.4 & 169 & 98.8 & $350(98.6)$ \\
\hline Mention the type of disease if not washing hands? & 179 & 97.3 & 165 & 96.5 & $344(96.9)$ \\
\hline How long does it take to wash hands with soap? & 47 & 25.5 & 34 & 19.9 & $81(22.8)$ \\
\hline What are the essential benefits of washing hands with soap? & 156 & 84.8 & 159 & 93.0 & $315(88.7)$ \\
\hline Mention the media that can be a place of transmission of diarrhea? & 159 & 86.4 & 152 & 88.9 & $311(87.6)$ \\
\hline With what do we rinse our hands after washing hands with soap? & 152 & 82.6 & 154 & 90.1 & $306(86.2)$ \\
\hline The last step to wash hands is? & 152 & 82.6 & 152 & 88.9 & $304(85.6)$ \\
\hline What does PHBS stand for? & 159 & 86.4 & 152 & 88.9 & $311(87.6)$ \\
\hline
\end{tabular}

Tabel 5. Relationship between facility facilities, knowledge and other factors to the behavior of handwashing with student soap (HWWS)

\begin{tabular}{|l|c|c|c|c|c|c|}
\hline Variable & \multicolumn{2}{|c|}{ Less } & \multicolumn{2}{c|}{ Good } & p-value & OR (95\% CI) \\
\hline & $\mathbf{n}$ & $\%$ & $\mathbf{n}$ & $\%$ & & \\
\hline Gender & & & & & & \\
\hline $\begin{array}{l}\text { Meal } \\
\text { Female }\end{array}$ & 86 & 46.7 & 98 & 53.3 & 0.048 & $1.5(0.96-2.24)$ \\
\hline Age & & & & & & \\
\hline$\leq 10$ years & 116 & 43.1 & 153 & 56.9 & 0.323 & $1.2(0.71-1.90)$ \\
$>10$ years & 34 & 39.5 & 52 & 60.5 & & \\
\hline Facilities & & & & & & \\
\hline No & 50 & 54.3 & 42 & 45.7 & 0.005 & $1.94(1.2-3.14)$ \\
Yes & 100 & 38.0 & 163 & 62.0 & & \\
\hline Knowledge & & & & & & $1.8(1.10-2.86)$ \\
\hline Less & 49 & 52.7 & 44 & 47.3 & 0.025 & \\
Good & 101 & 38.5 & 161 & 61.5 & & \\
\hline Counseling & & & & & & $1.4(0.08-2.44)$ \\
\hline $\begin{array}{l}\text { No } \\
\text { Yes }\end{array}$ & 30 & 49.2 & 31 & 50.8 & 0.144 & \\
\hline
\end{tabular}

\section{Discussion}

The main findings of this study are the behavior of students who wash their hands with soap by $76.1 \%$, wash their hands with soap after small or large bowel movements by $88.7 \%$ and wash their hands with soap after handling animals by $82.0 \%$. These
Tabel 6. Logistic regression analysis of factors related to handwashing with soap (HWWS)

\begin{tabular}{|l|l|l|l|}
\hline Variable & OR & $(\mathbf{9 5} \% \mathbf{C I})$ & p-value \\
\hline Facilities & 1.9 & $1.15-3.03$ & 0.011 \\
\hline Knowledge & 1.7 & $1.05-2.75$ & 0.037 \\
\hline
\end{tabular}

findings are higher than the results of the 2018 Basic Health Research in Indonesia, where the proportion of the population aged $\geq 10$ years behaved properly handwashing at $49.0 \%{ }^{21}$. Studies in Kenya and Bangladesh support the findings of this study, where $31 \%$ and $88 \%$ of respondents had the behavior of washing their hands with soap after defecation ${ }^{26,27}$. Similarly, findings from research in Louisiana stated that there were $78.0 \%$ of respondents who reported washing their hands immediately after contact with animals. Human or animal droppings are the primary source of transmission of germs such as Salmonella, E. coli O157 and norovirus, which cause diarrhea and can spread several respiratory infections such as adenovirus and hand-foot-mouth disease ${ }^{28}$. Washing hands with soap is an easy and inexpensive way to reduce the risk of spreading disease-causing pathogens during contact with animals in the environment and after defecation.

The majority of students (77.2\%) did not know the length of time needed to wash their hands with soap. The recommended time to wash hands with soap ranges between 20-40 seconds ${ }^{7,8}$. However, from the results of previous studies, said that the average person is washing hands with soap less than 10 seconds ${ }^{29,30}$. How to wash hands properly, including rubbing 
hand with soap and use clean water for at least 20 seconds. Washing hands for 20 seconds is estimated to be enough to reach the entire surface of the skin of the hand, considering that there are wrinkles on the palms, nails, between the fingers, under the ring and scars on the fingers. Adequate time allows the soap to form foam containing surfactant molecules, where surfactants can bind and carry the remains of bacteria or viruses with the help of water.

This study shows that schools that do not have facilities for washing hands have 1.9 times higher potential for bad behavior when washing their hands. This finding is consistent with the results of research conducted by Jacqueline and Leontsini, where facilities and handwashing facilities are an essential component in the environment that allows for behavior change $\mathrm{e}^{31,32}$. If soap and water are always available in handwashing facilities, students will be 2-3 times more often to wash hands with soap than if there were none $e^{33-36}$. Some recent research considers how the physical environment can be modified to signal handwashing behavior (as a behavioral impulse $)^{37}$. Like painting with footprints as a guide to toilets and handwashing facilities ${ }^{38}$ placing eye pictures above handwashing facilities ${ }^{39}$ and putting toys in soap ${ }^{40}$ are proven to improve a person's handwashing behavior.

In this study, students who have profound knowledge 1.7 times higher potential to misbehave in washing hands. This finding is consistent with previous reports, where there is a gap between knowledge and practice/behavior of washing hands with soap ${ }^{27}$. Everyone has a basic understanding of disease transmission and can explain the benefits of simple hand washing, even in populations with low formal education levels ${ }^{27,41}$. However, several studies have shown that handwashing programs that only focus on increasing biomedical knowledge do not have an impact on behavior ${ }^{42-44}$. Because knowledge of biomedicine alone is not enough and does not always have an impact on improving healthy living behaviors, many other factors can be making behavior distracted $37,41,45,46$

From the observations in five schools, data on handwashing facilities were available, such as a permanent handwashing building, clean water, running water, hand soap and a permanent toilet. This result is still not by the results of student confirmation, where students who feel the availability of clean water sources $(97.7 \%)$, running water in the hand washing area $(82.0 \%)$, and the availability of soap in the hand washing area $(91.3 \%)$. Possibly because the availability of handwashing materials at the facility is not always available, so a small proportion of students feel absent when needed. Therefore, the availability of soap, clean water and clean bathroom facilities is a must because it can encourage students to wash their hands frequently.
This study shows that gender is not significantly related to students' handwashing behavior. These results are consistent with the results of research in the Cameroon, where there is no gender difference in handwashing behavior ${ }^{47}$. However, research reports in North America provide different fact, where female students tend to consistently wash their hands more frequently compared to their male friends and are more effective than the usage of hand sanitizers, and visual prompts ${ }^{48,49}$. High commitment to hand hygiene among women is part of their attitude to practice socially acceptable behavior. Also, men tend to ignore hand hygiene practices, especially when they are alone in the bathroom or when they are in a hurry ${ }^{50}$ but information about the knowledge level and $\mathrm{HH}$ behaviour of the general public is relatively limited. The findings of this cross-sectional study can substantially contribute to the understanding on the knowledge gap and public behaviour towards $\mathrm{HH}$, thereby providing information on gender-specific health promotion activities and campaigns to improve $\mathrm{HH}$ compliance. Methods: An epidemiological investigation by using a cross-sectional study design on the general public was conducted either via an online platform (Survey Monkey).

This research shows that age is not related to handwashing behavior. The results of this study are not consistent with research in Cameroon $^{47}$, Ghana ${ }^{51}$, and Bangladesh ${ }^{52}$ studies focusing on hand hygiene among university going students are not adequate in number. This study evaluated handwashing knowledge, practice, and other related factors among the selected university students in the city of Dhaka, Bangladesh. A cross-sectional study was conducted among 200 undergraduate students from four selected universities. A pretested, semi-structured questionnaire, that included a checklist associated with handwashing practice, was applied to capture all relevant data. The mean \pm SD where older age was significantly associated with lower knowledge scores for practice. These studies show that older students have lower hand hygiene knowledge and practice scores when compared to their younger counterparts. However, in the results of previous studies in Turkey, age was positively associated with handwashing practice knowledge scores ${ }^{53}$.

Now experts agree that washing hands with soap and clean water is effective in reducing the spread of disease-causing bacteria and viruses. But it needs to be known in one watch can become dirty like before washing ${ }^{54}$. The latest findings show that bacteria and viruses can last for hours, even days, when they land on objects made of plastic, metal and cardboard ${ }^{55}$. Constraints such as limited classrooms in urban environments tend to make classrooms crowded, thus allowing students to contact one another. Therefore it is necessary to focus interventions so that students wash their hands more often even if done in a shorter and more realistic time ${ }^{37}$. 


\section{Conclusion}

Washing hands of students still lack, especially among students who are in schools with inadequate facilities and have less knowledge about handwashing. The availability of soap, regular clean water and sanitation of clean bathroom facilities is a must and this can encourage students to wash their hands frequently. Hand hygiene education interventions need to be applied to create awareness about the importance of washing hands, increasing knowledge, practice and skills to wash hands properly (especially knowledge of the length of time to wash).

\section{Ethical Clearance}

The Research Ethics Permit from the National Institute of Research and Development Ethics Commission of the Ministry of Health of the Republic of Indonesia with the number LB.02.01/2/KE.243/2018.

\section{Conflict of Interest}

The authors declare that there is no conflict of interest regarding the publication of this paper.

\section{Acknowledgement}

Thank the Head of National Institute of Research and Development, Head of the Centre of Public Health Research and Development, who has given the confidence to carry out this Health Development Research. Thank Mrs. Sri Irianti, M.Phil. Ph.D. as supervisor of Health Development Research.

\section{References}

1. Liu L, Johnson HL, Cousens S, Perin J, Scott S, Lawn JE, et al. Global, regional and national causes of child mortality: An updated systematic analysis for 2010 with time trends since 2000. Lancet. 2012; 379(9832):2151-61. https://doi.org/10.1016/ S0140-6736(12)60560-1

2. Rachmat B, Susilowati A. Prevalence and determinants of fatigue among private high school students in Bogor Tengah Sub-District, Indonesia, 2016. J Ecophysiol Occup Heal. 2019; 19:136-43. https://doi.org/10.18311/jeoh/2019/24190

3. Moonie S, Sterling DA, Figgs LW, Castro M. The relationship between school absence, academic performance and asthma status. J Sch Health. 2008; 78(3):140-8. PMid: 18307609. https:// doi.org/10.1111/j.1746-1561.2007.00276.x

4. Dyer DL, Shinder A, Shinder F. Alcohol-free instant hand sanitizer reduces elementary school illness absenteeism. Fam Med. 2000; 32(9):633-8.

5. Haller L, Hutton G, Bartram J. Estimating the costs and health benefits of water and sanitation improvements at global level.
J Water Health. 2007; 5(4):467-80. PMid: 17878561. https://doi. org/10.2166/wh.2007.008

6. Aiello AE, Coulborn RM, Perez V, Larson EL. Effect of hand hygiene on infectious disease risk in the community setting: A meta-analysis. Am J Public Health. 2008; 98(8):1372-81. PMid: 18556606 PMCid: PMC2446461. https://doi.org/10.2105/ AJPH.2007.124610

7. World Health Organization. WHO guidelines on hand hygiene in health care. World Health. 2009.

8. Jensen DA, Danyluk MD, Harris LJ, Schaffner DW. Quantifying the effect of hand wash duration, soap use, ground beef debris and drying methods on the removal of Enterobacter aerogenes on hands. J Food Prot. 2015; 78(4):685-90. PMid: 25836392. https://doi.org/10.4315/0362-028X.JFP-14-245

9. Burton M, Cobb E, Donachie P, Judah G, Curtis V, Schmidt WP. The effect of handwashing with water or soap on bacterial contamination of hands. Int J Environ Res Public Health. 2011; 8(7):97-104. PMid: 21318017 PMCid: PMC3037063. https://doi. org/10.3390/ijerph8010097

10. Luby SP, Aeboatwalla M, Bowen A, Kenah E, Sharker Y, Hoekstra RM. Difficulties in maintaining improved handwashing behavior, Karachi, Pakistan. Am J Trop Med Hyg. 2009; 81(1):140-5. PMid: 19556579. https://doi.org/10.4269/ajtmh.2009.81.140

11. Luby SP, Agboatwalla M, Feikin DR, Painter J, Billhimer W, Altaf A, et al. Effect of handwashing on child health: A randomised controlled trial. Lancet. 2005; 366(9481):225-33. https://doi. org/10.1016/S0140-6736(05)66912-7

12. Talaat M, Afifi S, Dueger E, El-Ashry N, Marfin A, Kandeel A, et al. Effects of hand hygiene campaigns on incidence of laboratoryconfirmed influenza and absenteeism in schoolchildren, Cairo, Egypt. Emerg Infect Dis. 2011; 17(4):619-25. PMid:21470450 PMCid:PMC3377412. https://doi.org/10.3201/eid1704.101353

13. Bieri FA, Gray DJ, Williams GM, Raso G, Li YS, Yuan L, et al. Health-education package to prevent worm infections in Chinese schoolchildren. N Engl J Med. 2013; 368:1603-12. PMid: 23614586. https://doi.org/10.1056/NEJMoa1204885

14. Seale AC, Mwaniki M, Newton CR, Berkley JA. Maternal and early onset neonatal bacterial sepsis: Burden and strategies for prevention in sub-Saharan Africa. The Lancet Infectious Diseases. 2009; 9(7):428-38. https://doi.org/10.1016/S14733099(09)70172-0

15. Laxminarayan R, Chow J S-SS. Chapter 2. Intervention costeffectiveness: Overview of main messages. Disease Control Priorities in Developing Countries (2nd Ed). Washington (DC): The International Bank for Reconstruction and Development/ The World Bank; 2006. Chapter 2. Co-published by Oxford University Press, New York; 2006.

16. Jasper C, Le TT, Bartram J. Water and sanitation in schools: A systematic review of the health and educational outcomes. International Journal of Environmental Research and Public Health. 2012; 9(8):2772-87. PMid: 23066396 PMCid: PMC3447586. https://doi.org/10.3390/ijerph9082772

17. Garn JV, Greene LE, Dreibelbis R, Saboori S, Rheingans RD, Freeman MC. A cluster-randomized trial assessing the impact of school water, sanitation and hygiene improvements on pupil 
enrolment and gender parity in enrolment. J Water Sanit Hyg Dev. 2013; 3(4):592-601. PMid: 24392220 PMCid: PMC3876875. https://doi.org/10.2166/washdev.2013.217

18. Rosen L, Manor O, Engelhard D, Brody D, Rosen B, Peleg H, et al. Can a handwashing intervention make a difference? Results from a randomized controlled trial in Jerusalem preschools. Prev Med (Baltim). 2006; 42(1):27-32. PMid:16300823. https://doi.org/10.1016/j.ypmed.2005.09.012

19. WHO/UNICEF. Drinking water, sanitation and hygiene in schools. Global baseline report 2018 WHO/UNICEF Joint Monitoring Programme for Water supply, Sanitation and Hygiene. Unicef. 2018.

20. National Institute of Health Research and Development. National Report on Basic Health Research (Riskesdas) 2013. Ministry of Health of the Republic of Indonesia. Jakarta, Indonesia; 2013.

21. National Institute of Health Research and Development. National Report on Basic Health Research (Riskesdas) 2018. Ministry of Health of the Republic of Indonesia. Jakarta, Indonesia; 2018.

22. National Institute of Health Research and Development. National Report on Basic Health Research (Riskesdas) 2007. Ministry of Health of the Republic of Indonesia. Jakarta, Indonesia; 2008.

23. Ogston SA, Lemeshow S, Hosmer DW, Klar J, Lwanga SK. Adequacy of sample size in health studies. Biometrics. 1991; 47(1):347-8. https://doi.org/10.2307/2532527

24. Boone HN, Boone DA. Analyzing Likert data. J Ext. 2012;

25. Menard S. Applied logistic regression analysis. Applied Logistic Regression Analysis. 2011.

26. Coombes Y, Devine J. Introducing FOAM: A framework to analyze handwashing behaviors to design effective handwashing programs. Working paper. 2010. https://doi.org/10.1596/27924

27. Rabbi SE, Dey NC. Exploring the gap between hand washing knowledge and practices in Bangladesh: A cross-sectional comparative study. BMC Public Health. 2013; 13(1):89. PMid: 23363772 PMCid: PMC3564897. https://doi.org/10.1186/14712458-13-89

28. CDC. Show me the science - Why wash your hands? [internet]. Centers for Disease Control and Prevention. 2018 [cited 2020 Apr 29]. https://www.cdc.gov/handwashing/why-handwashing.html

29. Borchgrevink CP, Cha JM, Kim SH. Hand washing practices in a college town environment. J Environ Health. 2013; 75(8):18-24.

30. Lee MS, Hong SJ, Kim YT. Handwashing with soap and national handwashing projects in Korea: Focus on the National Handwashing Survey, 2006-2014. Epidemiol Health. 2015; 37: e2015039. PMid: 26725224 PMCid: PMC4652062. https://doi. org/10.4178/epih/e2015039

31. Jacqueline D. Beyond tippy-taps: The role of enabling products in scaling up and sustaining handwashing. Waterlines. 2010; 29(4):304-14.

32. Leontsini E, Winch PJ. Increasing handwashing with soap: Emotional drivers or social norms? Lancet Globe Heal [Internet]. 2014; 2(3):e118-9. Available from: http://dx.doi.org/10.1016/ S2214-109X(14)70030-0

33. Nizame FA, Leontsini E, Luby SP, Nuruzzaman M, Parveen $S$, Winch PJ, et al. Hygiene practices during food preparation in Rural Bangladesh: Opportunities to improve the impact of handwashing interventions. Am J Trop Med Hyg. 2016; 95(2):288-97. PMid: 27296388 PMCid: PMC4973173. https:// doi.org/10.4269/ajtmh.15-0377

34. Luby SP, Halder AK, Tronchet C, Akhter S, Bhuiya A, Johnston RB. Household characteristics associated with handwashing with soap in rural Bangladesh. Am J Trop Med Hyg. 2009; 81(5):8827. PMid:19861626. https://doi.org/10.4269/ajtmh.2009.09-0031

35. Oswald WE, Hunter GC, Kramer MR, Leontsini E, Cabrera L, Lescano AG, et al. Provision of private, piped water and sewerage connections and directly observed handwashing of mothers in a peri-urban community of Lima, Peru. Trop Med Int Heal. 2014; 19(4):388-07. PMid: 24438038 PMCid: PMC4098569. https:// doi.org/10.1111/tmi.12262

36. Hirai M, Graham JP, Mattson KD, Kelsey A, Mukherji S, Cronin AA. Exploring determinants of handwashing with soap in Indonesia: A quantitative analysis. Int J Environ Res Public Health. 2016; 13(9):868. PMid: 27598178 PMCid: PMC5036701. https://doi.org/10.3390/ijerph13090868

37. White S. How can handwashing implementers consistently integrate the latest evidence in their work? [Internet]. The Global Handwashing Partnership. 2019 [cited 2020 Apr 22]. p. 1. https:// globalhandwashing.org/how-can-handwashing-implementersconsistently-integrate-the-latest-evidence-in-their-work/

38. Dreibelbis R, Kroeger A, Hossain K, Venkatesh M, Ram PK. Behavior change without behavior change communication: Nudging handwashing among primary school students in Bangladesh. Int J Environ Res Public Health. 2016; 13(1):E129. PMid: 26784210 PMCid: PMC4730520. https://doi.org/10.3390/ ijerph13010129

39. Pfattheicher S, Strauch C, Diefenbacher S, Schnuerch R. A field study on watching eyes and hand hygiene compliance in a public restroom. J Appl Soc Psychol. 2018; 48(4):188-94. https://doi. org/10.1111/jasp.12501

40. Watson J, Dreibelbis R, Aunger R, Deola C, King K, Long S, et al. Child's play: Harnessing play and curiosity motives to improve child handwashing in a humanitarian setting. Int J Hyg Environ Health. 2019; 222(2):177-82. PMid: 30219482. https://doi. org/10.1016/j.ijheh.2018.09.002

41. Curtis VA, Danquah LO, Aunger R V. Planned, motivated and habitual hygiene behaviour: An eleven country review. Health Educ Res. 2009; 24(4):655-73. PMid: 19286894 PMCid: PMC2706491. https://doi.org/10.1093/her/cyp002

42. Scott E, Herbold N. An in-home video study and questionnaire survey of food preparation, kitchen sanitation and hand washing practices. J Environ Health. 2010; 72(10):8-13.

43. Biran A, Schmidt WP, Wright R, Jones T, Seshadri M, Isaac P, et al. The effect of a soap promotion and hygiene education campaign on handwashing behaviour in rural India: A cluster randomised trial. Trop Med Int Heal. 2009; 14(10):1303-14. PMid: 19708896. https://doi.org/10.1111/j.1365-3156.2009.02373.x

44. Contzen N, Meili IH, Mosler HJ. Changing handwashing behaviour in Southern Ethiopia: A longitudinal study on infrastructural and commitment interventions. Soc Sci Med. 2015; 124:103-14. PMid: 25461867 https://doi.org/10.1016/j. socscimed.2014.11.006 
45. Rheinländer T, Samuelsen H, Dalsgaard A, Konradsen F. Teaching minority children hygiene: Investigating hygiene education in kindergartens and homes of ethnic minority children in Northern Vietnam. Ethn Heal. 2015; 20(3):258-72. PMid: 24875851. https://doi.org/10.1080/13557858.2014.921887

46. Biran A, Tabyshalieva A, Salmorbekova Z. Formative research for hygiene promotion in Kyrgyzstan. Health Policy and Planning. 2005; 20(4):213-21. PMid: 15965033. https://doi.org/10.1093/ heapol/czi024

47. Mbouthieu Teumta GM, Niba LL, Ncheuveu NT, Ghumbemsitia MT, Itor POB, Chongwain P, et al. An institution-based assessment of students' hand washing behavior. Biomed Res Int. 2019; 2019:7178645. PMid: 31950052 PMCid: PMC6949676. https://doi.org/10.1155/2019/7178645

48. Anderson JL, Warren CA, Perez E, Louis RI, Phillips S, Wheeler J, et al. Gender and ethnic differences in hand hygiene practices among college students. Am J Infect Control. 2008; 36(5):361-8. PMid: 18538703. https://doi.org/10.1016/j.ajic.2007.09.007

49. Thumma J, Aiello AE, Foxman B. The association between handwashing practices and illness symptoms among college students living in a university dormitory. Am J Infect Control. 2009; 37(1):70-2. PMid: 18834732. https://doi.org/10.1016/j. ajic.2007.12.008

50. Suen LKP, So ZYY, Yeung SKW, Lo KYK, Lam SC. Epidemiological investigation on hand hygiene knowledge and behaviour: A cross-sectional study on gender disparity. BMC Public Health.
2019; 29(1):401. PMid: 30975130 PMCid: PMC6460727. https://doi.org/10.1186/s12889-019-6705-5

51. Prah J, Abdulai MS, Lasim OO, Emmanuel Walker AA-A. Assessment of hygiene practices among students at the University of Cape Coast, Ghana. Int Res J Public Heal. 2018; 2(21):1-9.

52. Sultana M, Alam Mahumud R, Razzaque Sarker A, Mahmud Hossain S. Hand hygiene knowledge and practice among university students: Evidence from private universities of Bangladesh. Risk Manag Healthc Policy. 2016; 2016:13-20. PMid: 26929673 PMCid: PMC4758791. https://doi.org/10.2147/ RMHP.S98311

53. Ergin A, Bostanci M, Onal O, Bozkurt AI, Ergin N. Evaluation of students' social hand washing knowledge, practices and skills in a university setting. Cent Eur J Public Health. 2011; 19(4):222-7. PMid: 22432398. https://doi.org/10.21101/cejph.a3664

54. Devamani C, Norman G. A simple microbiological tool to evaluate the effect of environmental health interventions on hand contamination. Int J Environ Res Public Health. 2014; 11(11):11846-59. PMid: 25407420 PMCid: PMC4245647. https://doi.org/10.3390/ijerph111111846

55. van Doremalen N, Bushmaker T, Morris DH, Holbrook MG, Gamble A, Williamson BN, et al. Aerosol and surface stability of SARS-CoV-2 as compared with SARS-CoV-1. N Engl J Med. 2020; 1-13. PMCid: PMC7121658. https://doi. org/10.1101/2020.03.09.20033217 